\title{
Wear behavior of zirconia-bazed ceramics under high-speed dry sliding on steel
}

Sergey N. KuLkov - Institute of Strength Physics and Materials Science SB RAS
Nikolal L. SAvchenko - Institute of Strength Physics and Materials Science SB RAS

Cirkónium-dioxid alapú kerámiák kopási viselkedése acélon történő nagy sebességú száraz csúszás esetében

Tanulmányoztuk a cirkónium-dioxid alapú kerámia kompozit anyagok viselkedését, acélon történō, nagy sebességú száraz csúszás esetében. A vizsgálatot tû-a-tárcsán módszerrel végeztük, maximálisan 47 m/s sebességgel. Kimutattuk, hogy a vizsgálat során egy nagyon komplex összetételú közbülsố réteg alakul ki, és ez szabályozza a kerámia-acél páros nem monoton kopását és súrlódási viselkedését. Az elsố fázisban a kopás normális mértékú, ami azonban katasztrófálisan megnövekszik. A második fázisban a kopás mértéke csaknem az eredeti értékig csökken (amilyen a kis, 0,1 m/s sebességnél tapasztalható). Az ilyen sebességtartományban az anyag gyakorlatilag nem mutat kopást.

\section{Introduction}

The development of industry requires the design of new wear resistant materials that are able to work in the widest possible range of speeds and loads [1]. Transformation-toughened ceramics are shown much promise for being applied in heavily loaded friction units [2]. Of special note among them are ceramics on the basis of yttria-stabilized tetragonal zirconia polycrystals (Y-TZP [2]). The major toughening mechanism for Y-TZP ceramics is the phase transformation from the tetragonal $\mathrm{ZrO}_{2}$ phase to monoclinic, which occurs under applied stresses [2]. Besides this, composites $\mathrm{Y}-\mathrm{TZP}-\mathrm{Al}_{2} \mathrm{O}_{3}$ are widely applied due to their high thermal stability [2] in which $\mathrm{Al}_{2} \mathrm{O}_{3}$ particles play a role of reinforcement phase. Our preliminary researches [3] of wear process in zirconia based ceramics with different content of $\mathrm{Al}_{2} \mathrm{O}_{3}$ carried out in speeds 0,2-9,4 $\mathrm{m} / \mathrm{s}$ and pressures 1-10 MPa have shown that wear rate has a maximum at pressures 5-10 MPa and speeds about $5 \mathrm{~m} / \mathrm{s}$.

It should be noted that there are currently no sufficient data on the behavior of such materials at high sliding speeds, above $10 \mathrm{~m} / \mathrm{s}$. The main emphasis is now put on studying the material behavior at low speeds (up to $1 \mathrm{~m} / \mathrm{s}$ ) under abrasive wear [4-5], at cutting and polishing [4-5].

At the same time, in order to choose an optimal structure of composites and their possible application areas, it is necessary to gain data on friction and wear and to study structural changes in composites in speed intervals characterized by high temperatures in the tribocontact zone.

Particularly, at sliding speed increase above $10 \mathrm{~m} / \mathrm{s}$ temperature in the tribocontact grows, which can significantly change the structural phase state of the composite material and its tribotechnical properties. As shown in [6], under high-speed friction of $\mathrm{SiC}-\mathrm{Al}_{2} \mathrm{O}_{3}-\mathrm{Al}$ composite on steel the coefficient of friction and wear decreases due to the formation of a layer containing various oxide mixtures on the friction surface. At elevated contact temperatures this layer has low shear stability, playing the role of lubricant [6]. Similar cases of preserving high tribological characteristics and protective function of transfer layers formed in high-speed friction on steel have
Prof. Sergey N. Kulkov is head of Department of Ceramics in the Institute of Strength Physics and Materials Science of the Russian Academy of Science since 1989. He has got scientific degrees "Candidate of Physics and Mathematical Sciences" at Tomsk State University in 1981; and "Doctor of Physics and Mathematica Sciences" in 1990. Since 1992 he's working as professor both in Tomsk State University and in Tomsk Polytechnik University. Professor Kulkov has a wide range experiments in research of structura ceramic composites and in development of new material composition and technology of high-tech products. His research works are represented in 5 books, more than 150 articles, 18 patents and many International Symposiums and Conferences. In 1997. prof. Kulkov had a Soros Professor grant. At present prof. Sergey N. Kulkov is head of chair .Theory of Strength and Mechanic of Solids", member of "The American Ceramic Society” of „The APMI- International" and the DYMAT Society (France) His scientific activities are the followings: ceramic matrix composites with transformation toughening ransformations and mechanical properties, shockwave treatment of ceramic powders, superplasticity of CMC, ceramic and ceramic reinforced metal fiber with high porosity for medical applications.

Nikolai L. Savchenko has finished the Tomsk Polytechnic University in 1987, and between 1991-1994 he was a PhD student of Institute of Strength Physics and Materials Science of Russian Academy of Sciences in Tomsk. In 1995 he successfully completed his dissertation work in theme of zirconia-based ceramics, and used to work as senior researcher in Institute of Strenght Physics and Materials Science of Russian Academy of Sciences. At present he is responsible for investigation of wear and friction of transformation-toughened ceramics and ceramic reinforced metal matrix composites on the base of tungsten and tungstenless hard alloys. Dr. Savchenko is author or co-author of 2 books - one of them published by Cambridge Interscience Publishing - of more than 40 articles and 5 Russian patent.

been discussed in $[7,8]$, which consider zirconia- and aluminabased ceramic materials. According to [8], at high sliding speeds up to $37 \mathrm{~m} / \mathrm{s}$ Y-TZP ceramic specimens demonstrate high wear resistance despite high temperatures in the tribocontact zone and related high-temperature phase transitions.

The present paper is aimed at studying tribological characteristics and the friction surface of Y-TZP and Y-TZP- $\mathrm{Al}_{2} \mathrm{O}_{3}$ after dry sliding on steel in a wide speed interval.

\section{Materials and experimental procedure}

Sliding tests were carried out on a friction machine UMT-1 using a pin-on-disk technique with a stepwise speed increase under dry friction. The disk was made of cast high-speed steel (HRC60) and rotated in the vertical plane. The test pressure made up 2-5 MPa, and the sliding speed varied up to $47 \mathrm{~m} / \mathrm{s}$. The test time was chosen so that the sliding distance at all speeds amounted to 2000 meters. Prior to each test the specimens were grinded at speed $0,2 \mathrm{~m} / \mathrm{s}$ and pressure $2 \mathrm{MPa}$ to get friction surfaces of specified geometry. In every experiment the friction force moment was recorded by the computer at 1 sec intervals and later it was recalculated into the friction coefficient. The measure of wear intensity was the ratio between the volume of the material removed from a specimen during test and sliding distance. The structure and phase composition of friction surfaces were examined with X-ray structural analysis, optical and scanning electron microscopy.

The ceramic specimens has composition of $\mathrm{ZrO}_{2}+3$ mole $\% \mathrm{Y}_{2} \mathrm{O}_{3}$ and 80 wt. $\% \mathrm{ZrO}_{2}\left(3\right.$ mole $\left.\% \mathrm{Y}_{2} \mathrm{O}_{3}\right)+20$ wt. $\% \mathrm{Al}_{2} \mathrm{O}_{3}$. 
This ceramics are characterized by high flexure strength, namely, $\approx 800 \mathrm{MPa}$ for Y-TZP and $\approx 900 \mathrm{MPa}$ for $\mathrm{Y}-\mathrm{TZP}-\mathrm{Al}_{2} \mathrm{O}_{3}$, as well as high fracture toughness $\left(\mathrm{K}_{1 \mathrm{c}}\right) \approx 13 \mathrm{MPa} \times \mathrm{m}^{1 / 2}$ for $\mathrm{Y}$-TZP and $\approx 10 \mathrm{MPa} \times \mathrm{m}^{1 / 2}$ for $\mathrm{Y}-\mathrm{TZP}-\mathrm{Al}_{2} \mathrm{O}_{3}$, and grain size $\approx 2 \mu \mathrm{m}$ for $\mathrm{Y}-\mathrm{TZP}$ and $\approx 1.5 \mu \mathrm{m}$ for $\mathrm{Y}-\mathrm{TZP}-\mathrm{Al}_{2} \mathrm{O}_{3}$. Both ceramics had $5 \%$ porosity and similar phase composition - $90 \%$ tetragonal and $10 \%$ of cubic phases.

\section{Results and discussion}

The performed tests have shown that at sliding speed growth the wear intensity of ceramics firstly increase and then decrease with speed growth, Fig. 1a, Fig. 2a. The friction coefficient for both ceramics reduced from $0,5-0,8$ at low sliding speeds to $\approx 0,15-0,2$ for $25-47 \mathrm{~m} / \mathrm{s}$, Fig. $1 \mathrm{~b}, 2 \mathrm{~b}$. By the electron scanning and optical microscopy data, friction in the speed interval up to $1 \mathrm{~m} / \mathrm{s}$ results in the formation of grooved surface typical of abrasive wear. Above sliding speeds $3 \mathrm{~m} / \mathrm{s}$ the worn surfaces have large areas with traces of pitting, and at speeds above $6 \mathrm{~m} / \mathrm{s}$ they appear smoother, Fig. 3, a, b. Of special note is that there is a network of cracks on friction surfaces of Y-TZP and Y-TZP- $\mathrm{Al}_{2} \mathrm{O}_{3}$ which divides the surface into separate fragments. We have measured crack spacings along the sliding direction and found that their size distributions are nearly normal with a clear peak.

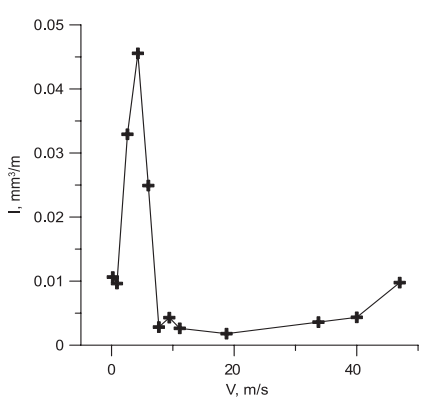

(a)

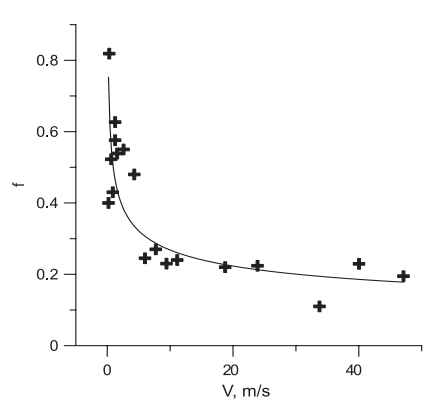

(b)
Fig. 1. The sliding speed dependence of the wear rate (a), the friction coefficient ( $b$ ) of $Y$-TZP ceramic. The contact pressure is $5 \mathrm{MPa}$.

1. ábra AzY-TZP kerámia kopásának mértéke (a) és súrlódási együtthatója (b) a csúszási sebesség függvényében. Érintkezési nyomás: $5 \mathrm{MPa}$.

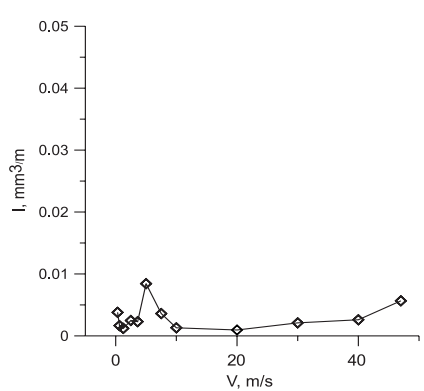

(a)

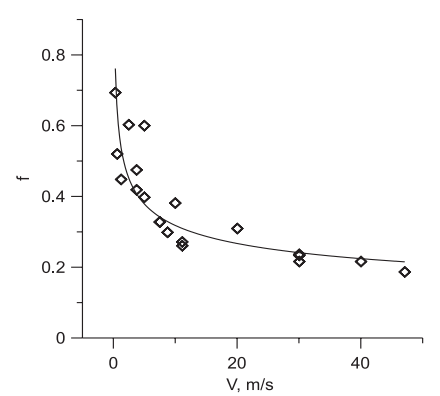

(b)
Fig. 2. The sliding speed dependence of the wear rate (a), the friction coefficient (b) of $\mathrm{Y}$-TZP-Al $\mathrm{O}_{3}$ ceramic. The contact pressure is $5 \mathrm{MPa}$.

2. ábra $\mathrm{AzY}-\mathrm{TZP}-\mathrm{Al}_{2} \mathrm{O}_{3}$ kerámia kopásának mértéke (a) és súrlódási együtthatója (b) a csúszási sebesség függvényében. Érintkezési nyomás: $5 \mathrm{MPa}$.

The monoclinic phase in initial state of both ceramics is absent and is appeared only after testing with speeds up to $2 \mathrm{~m} / \mathrm{s}$ for $\mathrm{Y}-\mathrm{TZP}$ and $11 \mathrm{~m} / \mathrm{s}$ for $\mathrm{Y}-\mathrm{TZP}-\mathrm{Al}_{2} \mathrm{O}_{3}$ and its volume fraction is about $7-15 \%$.
The amount of cubic phase which was $10 \%$ for initial state of ceramics remain invariable for $\mathrm{Y}-\mathrm{TZP}$ and $\mathrm{Y}-\mathrm{TZP}-\mathrm{Al}_{2} \mathrm{O}_{3}$ until reaching the speed of $20 \mathrm{~m} / \mathrm{s}$. The further increase in the sliding speed resulted in its $\approx 17 \%$ increase for $\mathrm{Y}-\mathrm{TZP}$ and $\approx 15 \%$ for $\mathrm{Y}-\mathrm{TZP}-\mathrm{Al}_{2} \mathrm{O}_{3}$ ceramics. The appearance of the cubic phase on the specimen surface after maximum sliding speeds is evidently due to that part of the tetragonal phase transforms to cubic by the diffusion mechanism. This transition is favored by high temperatures in the tribocontact zone, e.g., in [9] temperature in the tribocontact zone at speed $10 \mathrm{~m} / \mathrm{s}$ is estimated to be $\sim 2000^{\circ} \mathrm{C}$.
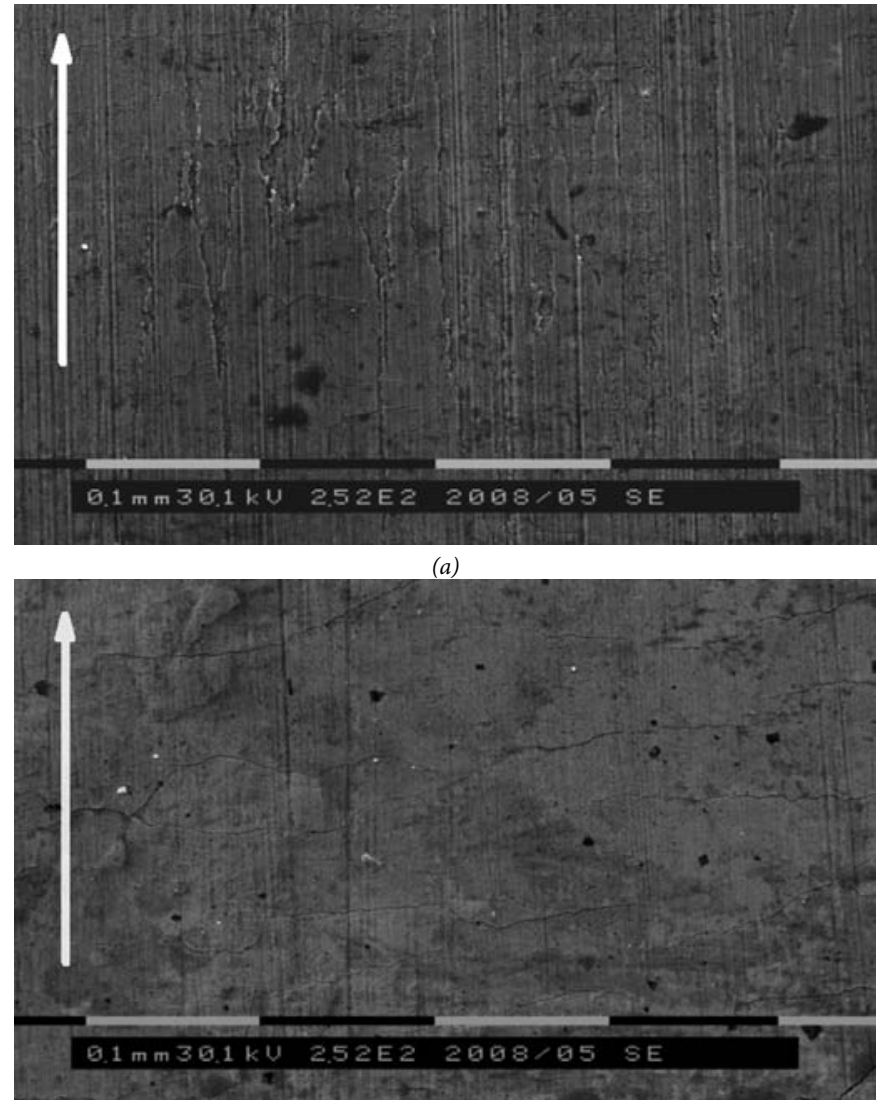

(b)

Fig. 3. The SEM micrographs of the wear surface of $Y-T Z P(a) Y-T Z P-A l_{2} \mathrm{O}_{3}(b)$ after tests at $47 \mathrm{~m} / \mathrm{s}$. Arrow shows the sliding direction.

3. ábra Az Y-TZP (a) és Y-TZP-Al $O_{3}$ (b) kerámiák koptatási felületének pásztázó elektronmikroszkópos (SEM) felvétele a $47 \mathrm{~m} / \mathrm{s}$ sebességü vizsgálat után. A nyil a csúszás irányát mutatja.

Optical and scanning electron microscopy revealed that above high speeds (higher than $6 \mathrm{~m} / \mathrm{s}$ ) friction surfaces were uniformly covered with a transfer layer. After low- and medium- speed sliding friction the transfer layer distribution on the surfaces was extremely inhomogeneous, which appeared as large friction surface areas with absolutely no transfer layer.

We have also examined near-surface regions of the Y-TZP ceramics and found that this surface layer (evidently having submicrocrystalline structure, Fig. 4a) is rather thin, about $1-2 \mu \mathrm{m}$. In the speed interval from 0,2 to $6 \mathrm{~m} / \mathrm{s}$ where the wear rate rapidly increases, there is a material region beneath the layer in which the grain shape is significantly changed in the sliding direction, Fig. 4a. The thickness of this region is maximum $10 \mu \mathrm{m}$ at medium sliding speeds $(\sim 4 \mathrm{~m} / \mathrm{s})$, i.e. at the 


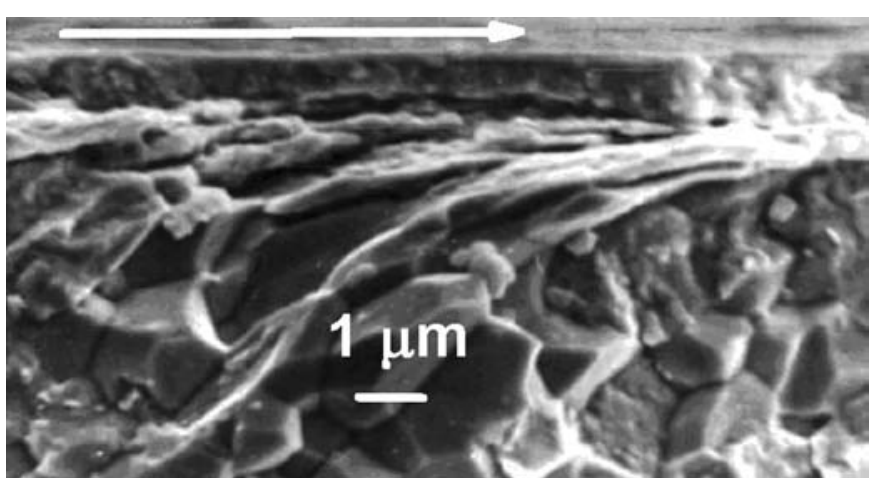

(a)

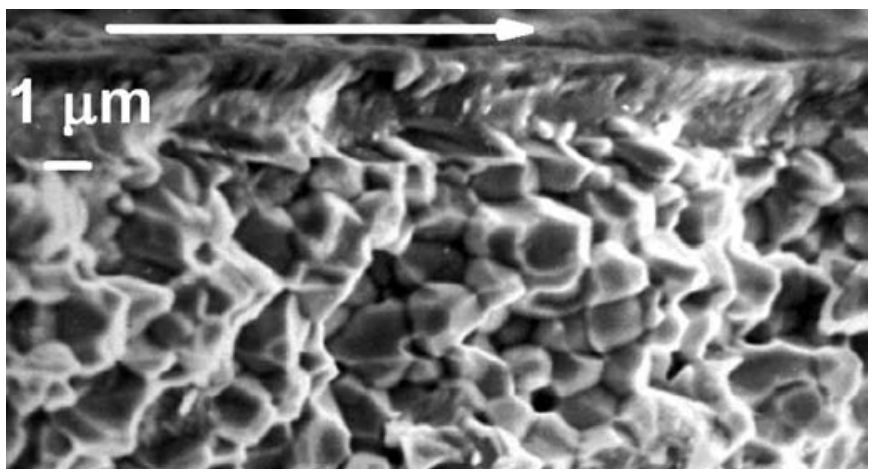

(b)

Fig. 4. The SEM micrographs of the subsurface regions of the Y-TZP ceramics after wear at (a) 4.3 and (b) $11.1 \mathrm{~m} / \mathrm{s}$. Arrow shows the sliding direction

4. ábra Az Y-TZP kerámiák felület alatti rétegének SEM felvétele a 4,3 (a) és a 11,1 (b) $\mathrm{m} / \mathrm{s}$ sebességü koptatás után. A nyíl a csúszás irányát mutatja.

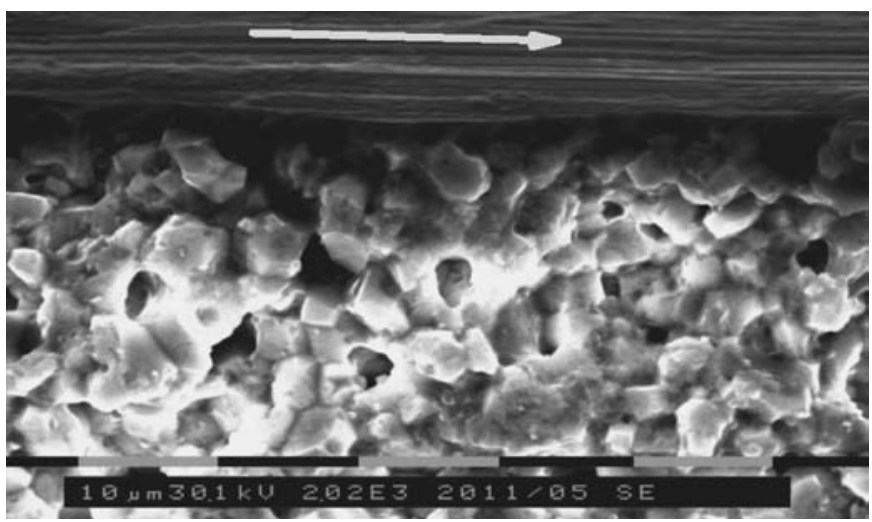

(a)

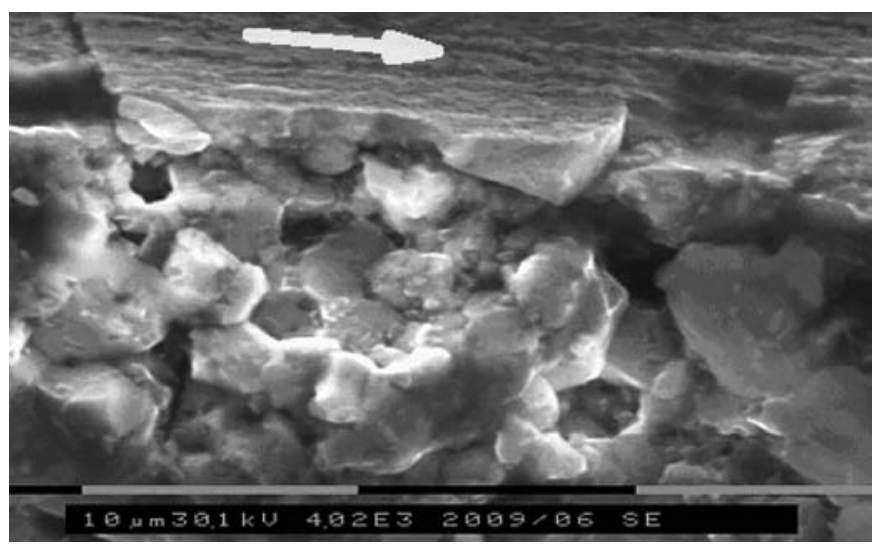

(b)

Fig. 5. The SEM micrographs of the subsurface regions of the $\mathrm{Y}-\mathrm{TZP}-\mathrm{Al}_{2} \mathrm{O}_{3}$ ceramics after wear at (a) 4.3 and (b) $40 \mathrm{~m} / \mathrm{s}$. Arrow shows the sliding direction.

5. ábra $\mathrm{Az} Y-\mathrm{TZP}-\mathrm{Al}_{2} \mathrm{O}_{3}$ kerámiák felület alatti rétegének SEM felvétele a 4,3 (a) és 40 (b) $\mathrm{m} / \mathrm{s}$ sebességü koptatás után. A nyíl a csúszás irányát mutatja. speeds when the wear rate is maximum, Fig. 1a. On increasing the sliding speed above $6 \mathrm{~m} / \mathrm{s}$, there is no changes of grain shapes they are approximately equiaxed alike in initial material Fig. 4b. In case of Y-TZP- $\mathrm{Al}_{2} \mathrm{O}_{3}$ ceramics these areas have never been found for all testing speeds even in average speeds of sliding where severe wear has been onserved (Fig. 5a, b).

The wear processes occurring at speeds $2-6 \mathrm{~m} / \mathrm{s}$ correspond to high-temperature adhesive interaction between ceramics and steel. This wear regime is characterized by high wear intensity, which is illustrated in Fig. 1a, Fig. 2a. Subsequent decrease in wear intensity at sliding speeds higher than $6 \mathrm{~m} / \mathrm{s}$ is a result of contact stress reduction owing to the formation of the transfer layer and its transition from the ductile to quasi-liquid state, which is also favored by high tribocontact temperature. The formed quasi-liquid film uniformly covers the ceramic friction surface and acts as "soft" coating. The latter facilitates contact stress decrease on the surface by reducing the true contact area between the specimen and disk. In case when the quasi-liquid "soft" film covers the ceramic surface, the friction coefficient is minimum and approaches values typical of boundary lubrication friction.

It should be noted that inspite of general similarity in tribology behaviour of samples of both Y-TZP and Y-TZP- $\mathrm{Al}_{2} \mathrm{O}_{3}$, the latter system shows a higher wear resistance under the conditions of high-speed sliding. It is possible that the microstructure of such a material serves to higher bearing ability of the worn surface.

\section{Conclusions}

The performed experiments have revealed that at high sliding speeds up to $47 \mathrm{~m} / \mathrm{s}$ Y-TZP and Y-TZP- $\mathrm{Al}_{2} \mathrm{O}_{3}$ ceramic specimens have high wear resistance, despite high temperatures in the tribocontact zone and related high-temperature transitions. In this case, there is a wide interval of speeds where the process is nearly "wearless".

We gratefully acknowledge the partial financial support from the RFBR (the project 06-03-96929-p_ofi).

\section{References}

[1] I.M. Fedorchenko (2002): Antifriction and friction cermet materials. Powder Metallurgy and Metal Ceramics, Vol.41/9-10, pp 489-497.

[2] L. Nettleship, R. Stevens (1987): Tetragonal zirconia polycrystal (TZP) - a review. Int.J. High Technology Ceramics, 3, pp 1-32.

[3] N. Savchenko, S. Tarassov, A. Melnikov, et al. (1998): Dry sliding wear resistance of toughened $\mathrm{ZrO}_{2}-\mathrm{Y}_{2} \mathrm{O}_{3}$ and $\mathrm{ZrO}_{2}-\mathrm{Y}_{2} \mathrm{O}_{3}-\mathrm{Al}_{2} \mathrm{O}_{3}$. Proc. of Euro. Conf. on Composite Materials. Science, Technologies and Applications (ECCM 8), 3-6 June 1998, Naples-Italy. Cambridge: Wodhead Publishing Limited, 4, pp 343-350.

[4] S.W. Lee, S.H. Hsu, M.C. Shen (1993): Ceramic Wear Maps: Zirconia J.Am.Ceram.Soc., Vol.76/8, pp 1937-1947.

[5] Y. J. He, A. J. A. Winnubst, A. J. Burggraaf, H. Verweij, P. G. van der Varst and B. de With (1996): Grain-size dependence of sliding wear in tetragonal zirconia polycrystals. J. Amer. Ceram. Soc., Vol.79/12, pp 3090-3096.

[6] A. Ravikiran, V. Jayaram, and S.K. Biswas (1997): Sliding wear of $\mathrm{Al}_{2} \mathrm{O}_{3}-\mathrm{SiC}-(\mathrm{Al}, \mathrm{Si})$ composites against a steel counterface. J.Am.Ceram.Soc., Vol.80/12, pp 19-24.

[7] A. Ravikiran, V. S. Nagarajan, S. K. Biswas, et al. (1995): Effect of speed and pressure on dry sliding interactions of alumina against steel. J. Am. Ceram. Soc., Vol.78/2, pp 356-364.

[8] N.L. Savchenko, K.M. Pyatova, S.N. Kulkov (2008): Vestnik TSU. Mathematics and mechanics, 1, pp 84-89 (in Russian)

[9] S.C. Lim, M.F. Ashby (1987): Wear mechanism maps. Acta Metallurgica, 35 , pp 1-24. 